\title{
Outburst flood evolution at Russell Glacier, western Greenland: effects of a bedrock channel cascade with intermediary lakes
}

Carrivick, Jonathan L.; Turner, Andy G.D.; Russell, Andrew J.; Ingeman-Nielsen, Thomas; Yde, Jacob C.

Publication date:

2013

Document Version

Publisher's PDF, also known as Version of record

Link back to DTU Orbit

Citation (APA):

Carrivick, J. L., Turner, A. G. D., Russell, A. J., Ingeman-Nielsen, T., \& Yde, J. C. (2013). Outburst flood evolution at Russell Glacier, western Greenland: effects of a bedrock channel cascade with intermediary lakes. Poster session presented at European Geosciences Union General Assembly 2013, Vienna, Austria.

\section{General rights}

Copyright and moral rights for the publications made accessible in the public portal are retained by the authors and/or other copyright owners and it is a condition of accessing publications that users recognise and abide by the legal requirements associated with these rights.

- Users may download and print one copy of any publication from the public portal for the purpose of private study or research.

- You may not further distribute the material or use it for any profit-making activity or commercial gain

- You may freely distribute the URL identifying the publication in the public portal 


\section{Outburst flood evolution at Russell Glacier, western Greenland:} effects of a bedrock channel cascade with intermediary lakes

Jonathan L. Carrivick', Andy G.D. Turner', Andrew J. RusselI', Thomas Ingeman-Nielsen ${ }^{3}$, Jacob C. Yde

\section{INTRODUCTION AND RATIONALE}

Quaternary glacial lake outburst floods (GLOFs), which are a type of jökulhlaup, were a key part of deglaciation from the Last Glacial Maximum (LGM). The very largest of these jökulhlaups affected climate via disruption of ocean thermohaline circulation. They were triggered by failure of a glacier ice dam and routed via a cascade of topographic bedrock basins and on occasions through pre-existing intermediary lakes. Quaternary outburst floods produced intense geomorphological impacts through excavation of onshore bedrock canyons and submarine canyons and redistribution of vast amounts of sediment across land and into oceans. Understanding of Quaternary outburst floods is generally restricted by a lack of modern analogues.

The overall aims of this study were to make the first systematic and detailed quantification of the effects of (i) intermediary lakes on the longitudinal and temporal hydraulic evolution of an outburst flood, and (ii) the effects of bedrock channel topography on outburst flood evolution

\section{STUDY SITE}

Russell Glacier, western Greenland (Fig. 1). Aflood occurred on $31^{\text {st }}$ August 2008.
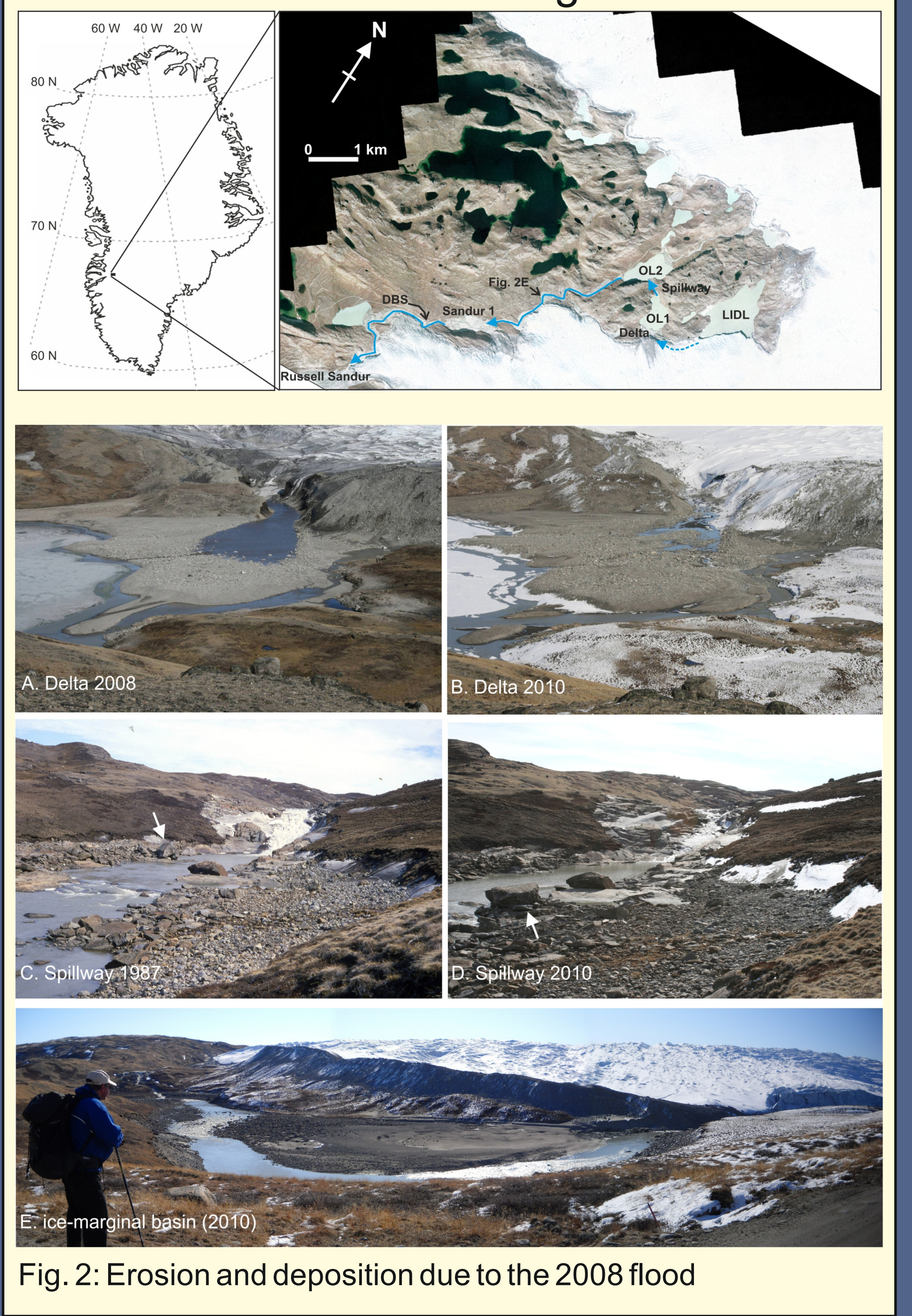

\section{WIDER IMPLICATIONS}

The Quaternary record of bedrock channelled outburst floods may be even more widespread than hitherto recognised, due to the fact that landforms and sediments of outburst floods can be exceptionally disparate, even from a single event.

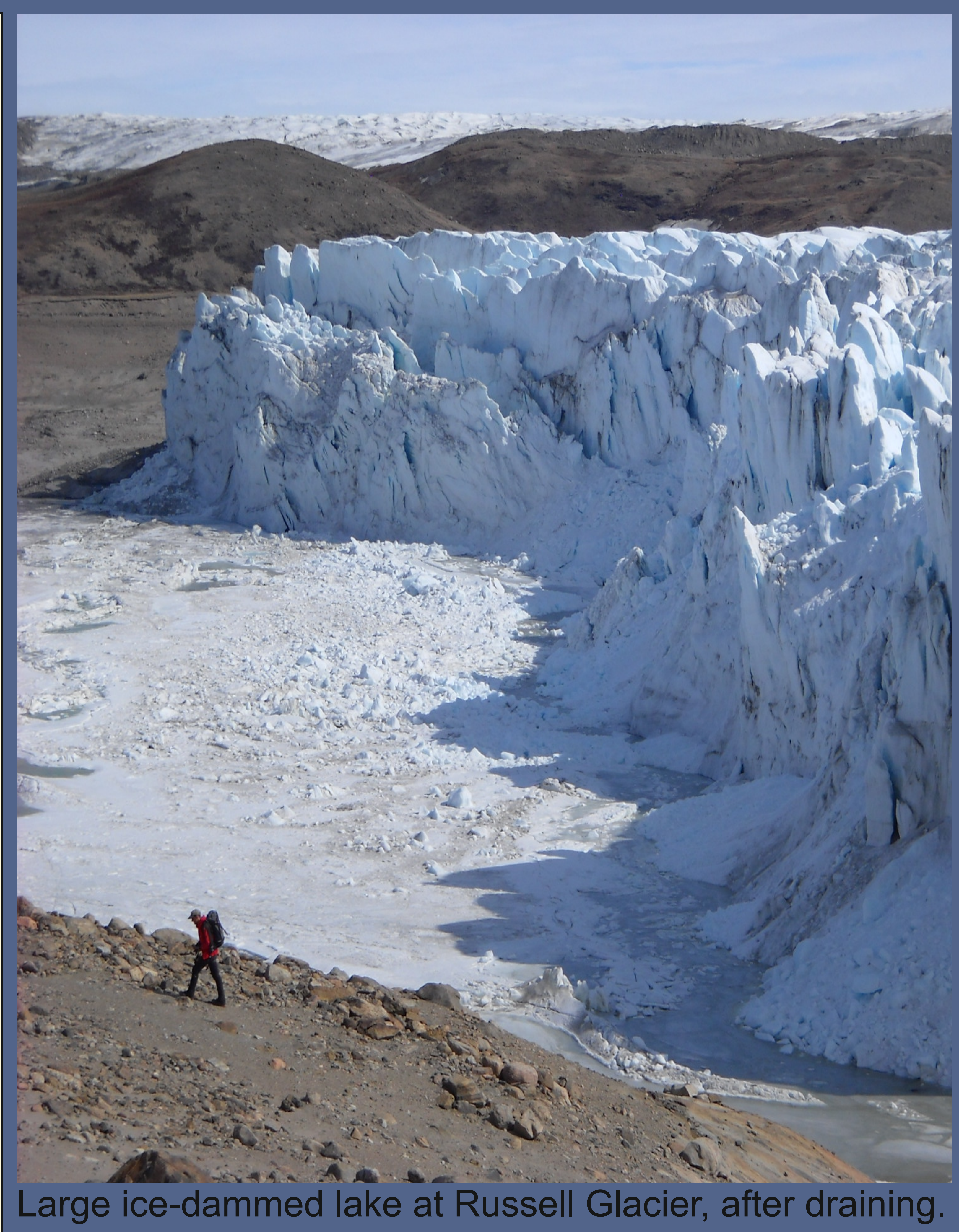

Fig. 3. Quantification of flood routeway channel.

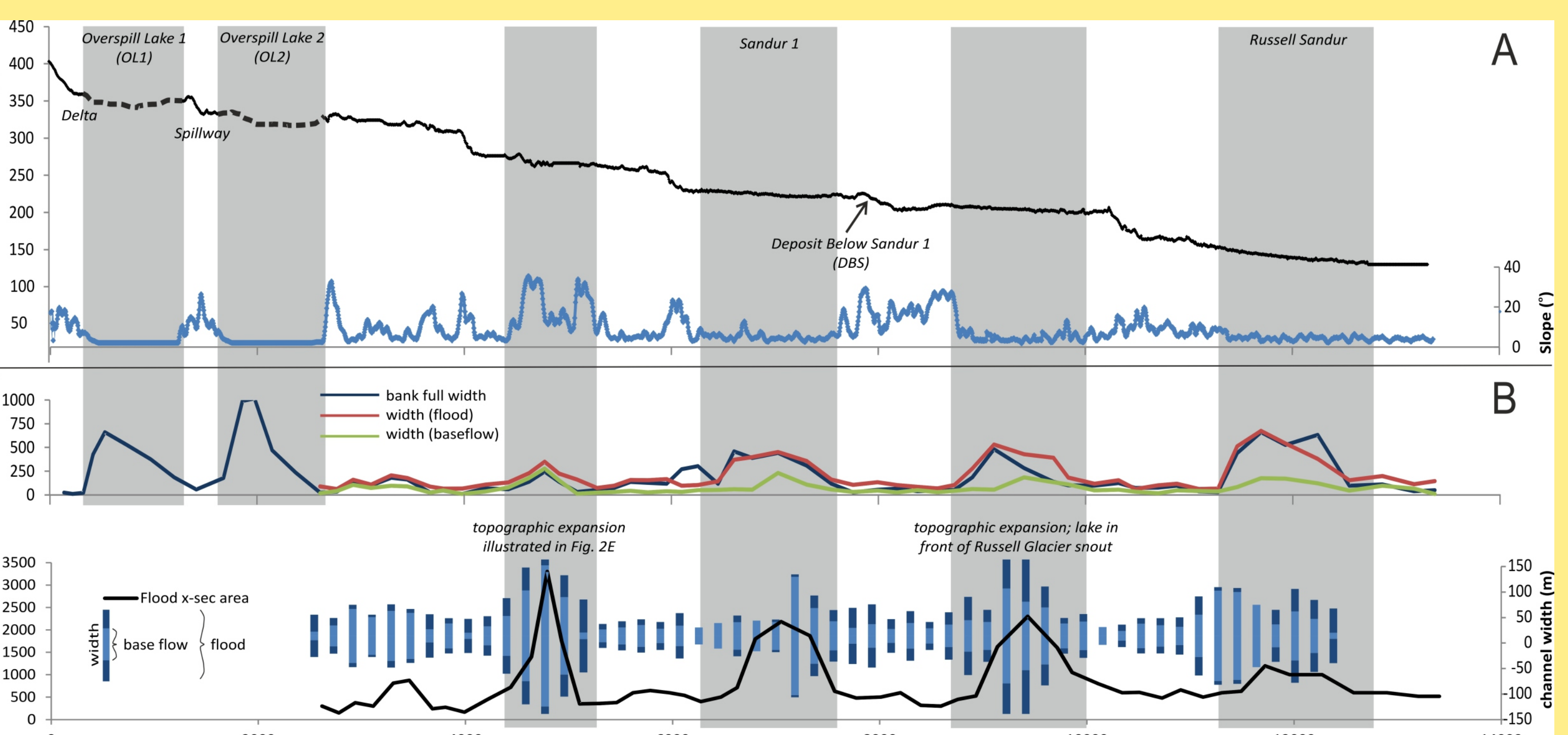

Fig. 4. Hydraulic reconstruction with Delft3d model.

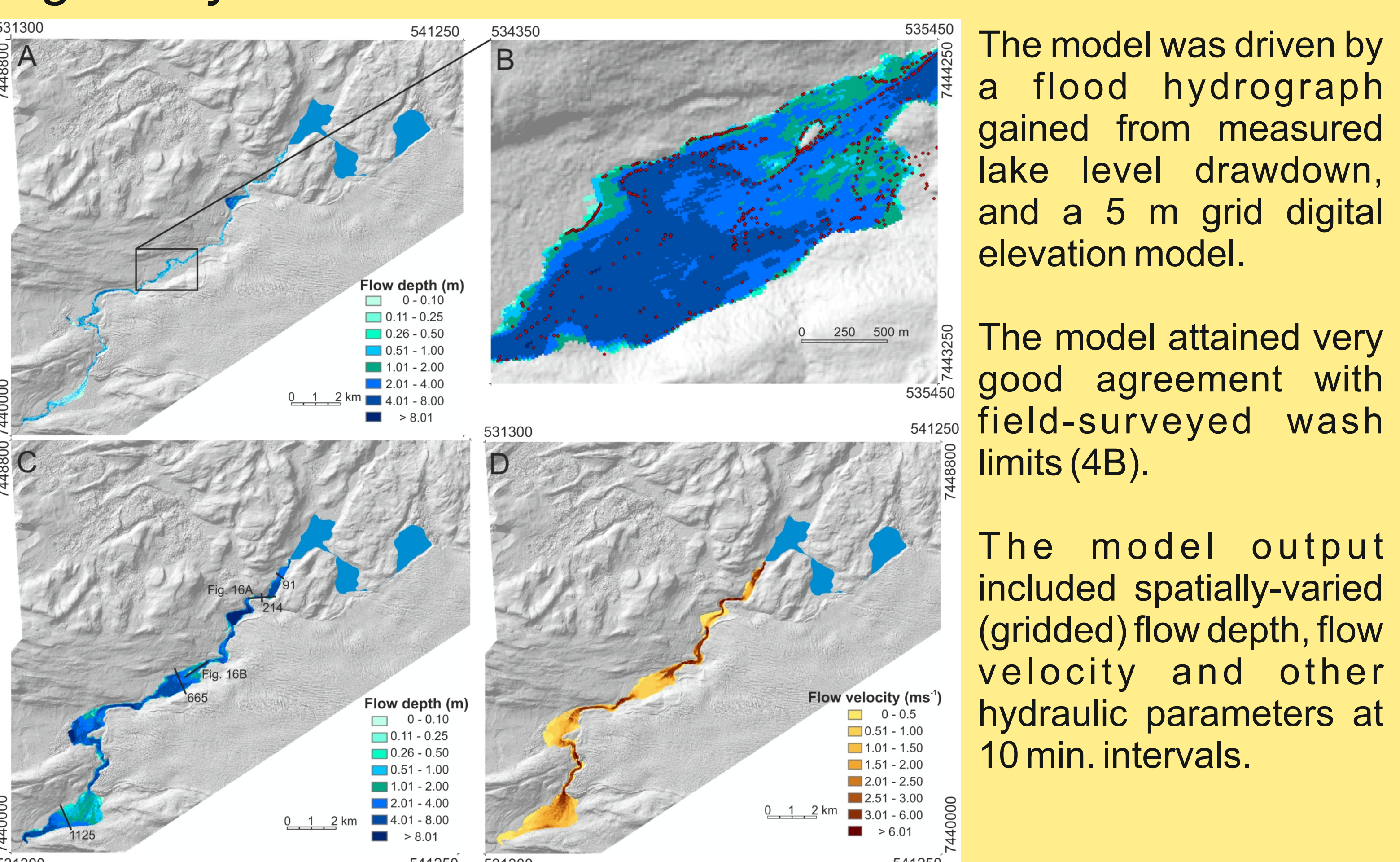

Gridded hydraulic variables were analysed using a bespoke program to calculate rate of rise to peak and duration of peak per cross section; see Figure 6.

\section{ACKNOWLEDGEMENTS}

JLC received financial support for field work from the School of Geography, University of Leeds. Meredith Williams helped with dGPS surveys in 2008. Aerial photograph . Kommunia. Kim Petersen is thanked for field logistics support.

\section{REFERENCES AND REPRINTS}

This paper is published in Quaternary Science Reviews.
please contact Jonathan Carrivick j.l.carrivick@leeds.ac.uk

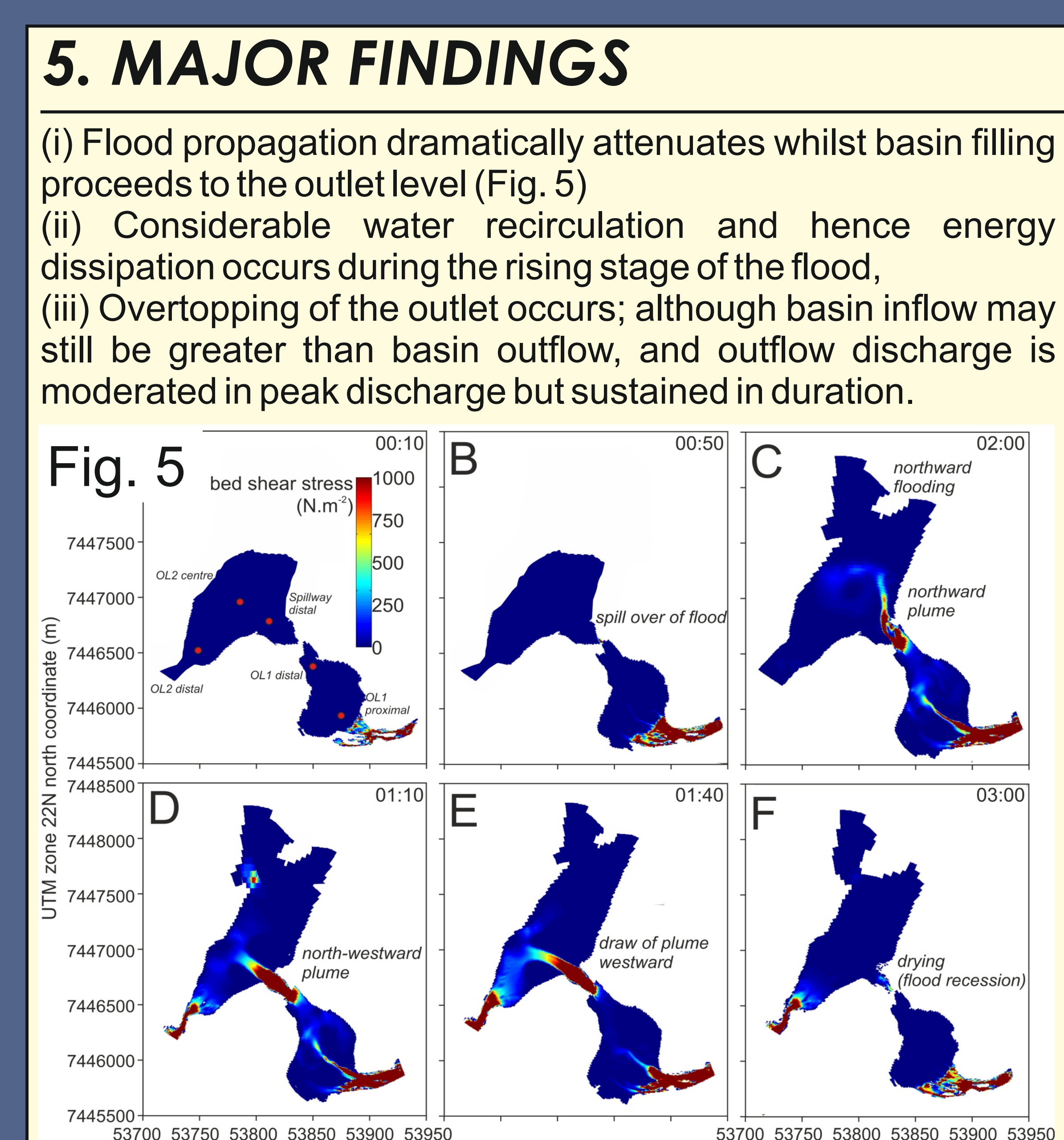

(iv) Bedrock channel topography can produce kinematic waves within an outburst flood via hydraulic ponding and these waves most likely account for hydropeaking (Fig. 6). (v) Evolution of bed shear stress can be decoupled from the evolution of flow depth due to the transition from channelized to sheet-like flow. (vi) Flood hydrograph shape evolves in bedrock channels with discharge faster as well as slower rates of rise to peak discharge and longer as well as shorter duration of peak discharge with distance down stream. (vii) Net whion along a channel

(1) can be related to alue and net deposition an be related to a 'time to peak' value (Fig. 6).

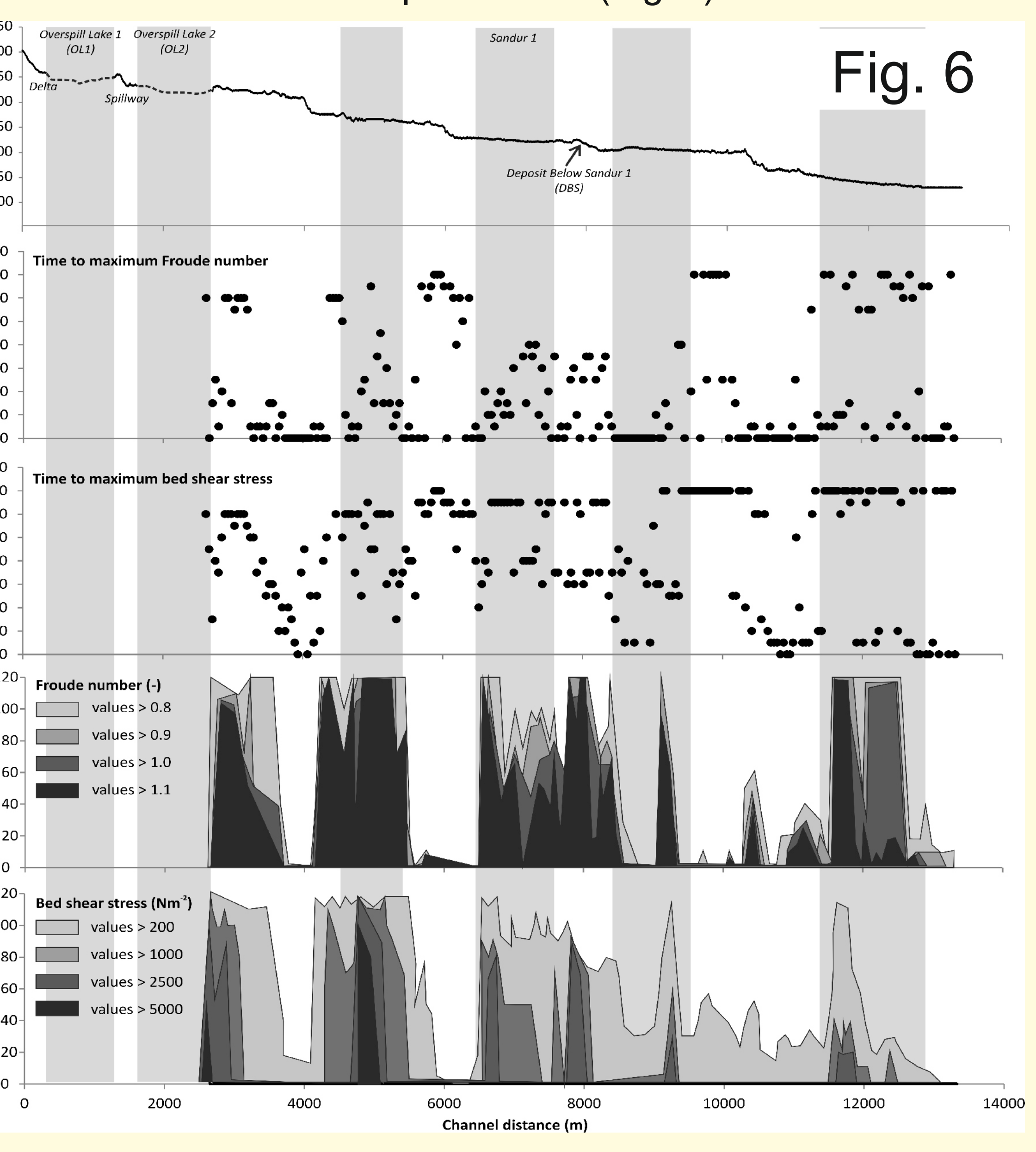

\section{CONCEPTUAL MODEL}
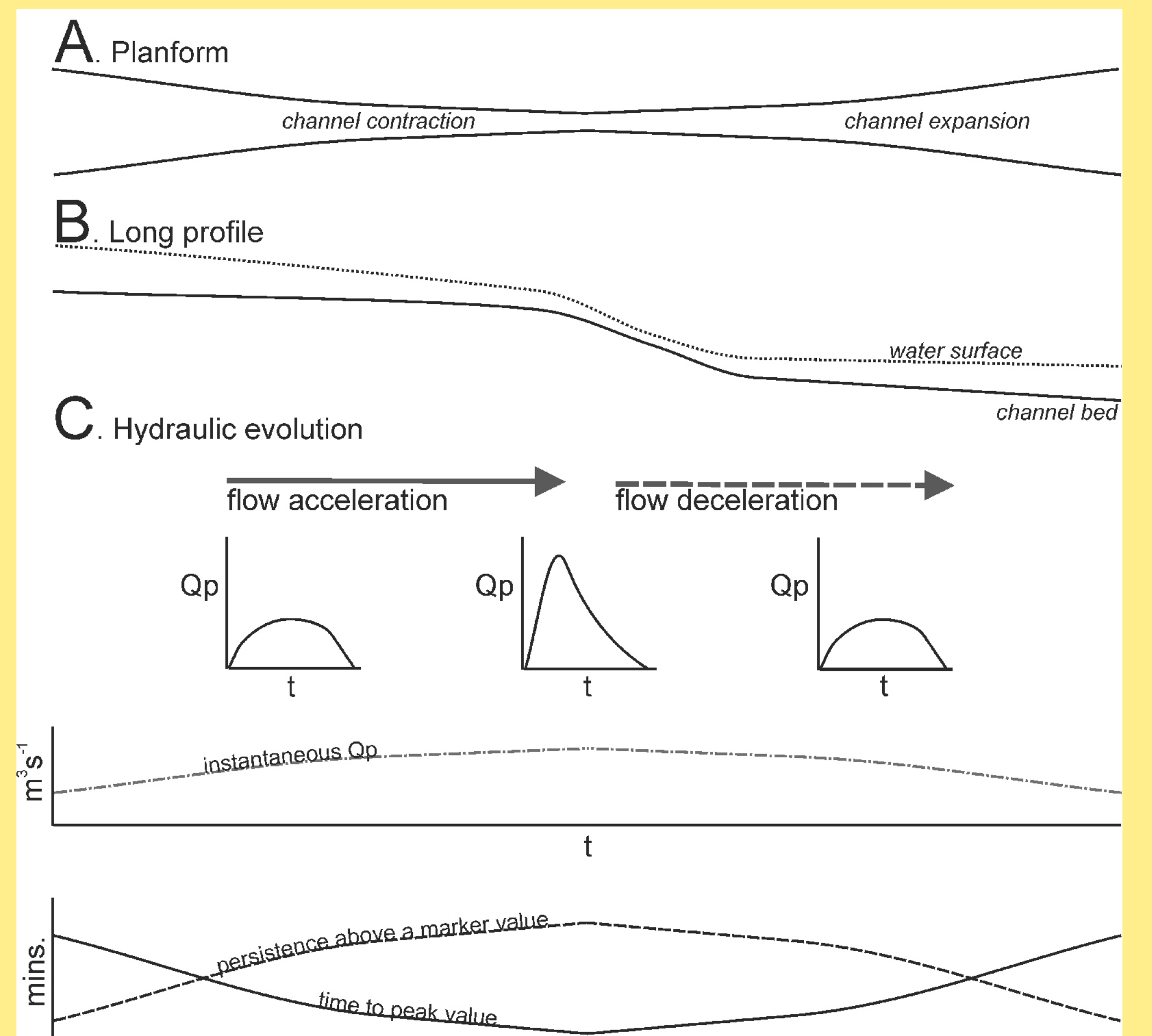

D. Geomorphological impact

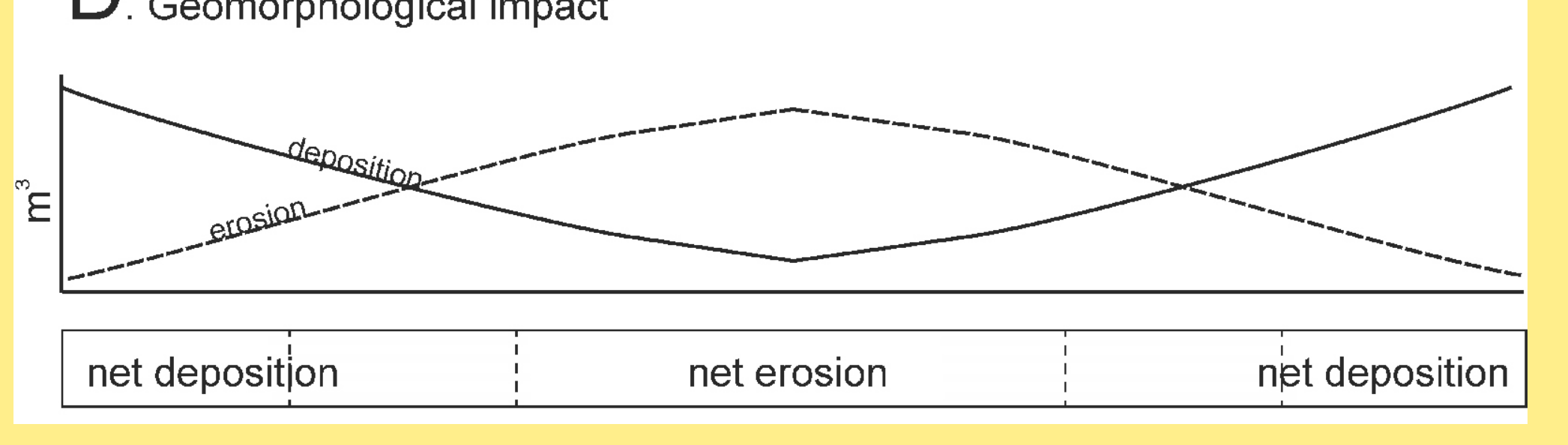

